PERM JOURNAL OF PETROLEUM AND MINING ENGINEERING ВЕСТНИК ПНИПУ. ГЕОЛОГИЯ. НЕФТЕТАЗОВОЕ И ГОРНОЕ ДЕЛО

ISSN 2224-9923

Volume/Tom 19 №2 2019

http://vestnik pstu.ru/geo/

UDC 622.276+552.2:504

Article / Статья

(C) PNRPU / ПНИПУ, 2019

\title{
ALTERATION IN COMPOSITION OF CLAYS SUBJECTED TO MAN-MADE IMPACT
}

\section{Karine A. Alvanyan, Aleksandr V. Rastegaev' ${ }^{1}$, Tatyana Yu. Khludeneva}

Perm State National Research University (15 Bukireva st., Perm, 614068, Russian Federation)

${ }^{1}$ Perm National Research Polytechnic University (29 Komsomolskiy av., Perm, 614990, Russian Federation)

\section{ИЗМЕНЕНИЕ СОСТАВА ГЛИН, ПОДВЕРЖЕННЫХ ТЕХНОГЕННОМУ ВОЗДЕЙСТВИЮ}

\section{К.А. Алванян, А.В. Растегаев ${ }^{1}$, Т.Ю. Хлуденева}

Пермский государственный национальный исследовательский университет (614068, Россия, г. Пермь, ул. Букирева, 15) ${ }^{1}$ Пермский национальный исследовательский политехнический университет (614990, Россия, г. Пермь, Комсомольский проспект, 29)

Получена / Received: 25.04.2019. Принята / Accepted: 01.06.2019. Опубликована / Published: 28.06.2019

\section{Keywords:}

clay, montmorillonite, kaolinite, granulometric composition, microaggregate composition, aggregation, dispergation, pressure, man-made impact, coagulation, transition and phase contacts.
Physical and chemical properties of clays depend on a group of factors determining energy potential on particle surface and on factors forming particle specific surface.

Particle specific surface formation is directly related to issues of microaggregates formation in soil. Studies of influence of pressure in aggregates formation in dispersive soils showed that at pressure up to $200 \mathrm{MPa}$ slight alteration in aggregate composition is observed in wet soils. At pressure $300 \mathrm{MPa}$ in powdery soil content of thin sandy fraction increased from 13 to $51 \%$, powdery fraction - from 5 to $23 \%$, and clay fraction - from 2,15 to 5,42\%. During test of covering loams with pressure $P=2000 \mathrm{MPa}$ and $P=3660 \mathrm{MPa}$ similar results were received. From the stated above it follows that issue of pressure influence on formation of microaggregate composition and, as result, physical and chemical properties of clay are of substantial interest.

Regularities in alteration of composition of clays subjected to high pressure were studied. As result of experimental studies, it is established that along with pressure increase general tendency of reduction of clay fraction content and increase of powdery fraction content is observed. Together with this regularity, local alterations of clay fractional composition depending on pressure in each class are found. Along with pressure increase, particle specific surface value of kaolin and montmorillonite clays reduces. Alterations in granulometric composition are determined by particle aggregation and dispergation processes. During aggregation process caused by high pressure coagulation, transition and phase contacts between particles are formed. Breaking and wedging pressure of adhesive water film around particles are leading factors determining process of their dispergation.

Физико-химические свойства глин зависят от группы факторов, определяющих энергетический потенциал на поверхности частиц, и от факторов, формирующих удельную поверхность частиц.

Формирование удельной поверхности частиц напрямую связано с вопросами образования микроагрегатов в грунтах. Исследования влияния давления на формирование агрегатов в дисперсных грунтах показали, что при давлениях до $200 \mathrm{MПа} \mathrm{наблюдается} \mathrm{незначительное} \mathrm{изменение} \mathrm{агрегатного} \mathrm{состава} \mathrm{сырых} \mathrm{грунтов.} \mathrm{При} \mathrm{давлении} 300$ МПа пылеватого грунта содержание тонкой песчаной фракции увеличилось от 13 до $51 \%$, пылеватой - от 5 до $23 \%$, а глинистой - от 2,15 до $5,42 \%$. При испытании покровных суглинков давлением $P=2000$ МПа и $P=3660$ МПа получены аналогичные результаты. Из приведенного выше следует, что вопросы влияния давления на образование микроагрегатного состава и, как следствие, физико-химических свойств глин представляют значительный интерес.

Исследованы закономерности изменения состава глин, подверженных высоким давлениям. В результате экспериментальных исследований установлено, что с увеличением давления наблюдается общая тенденция снижения содержания глинистой и увеличения пылеватой фракций. Наряду с этой закономерностью в каждом классе выявлены локальные изменения содержания фракционного состава глин в зависимости от давления. С увеличением давления площадь удельной поверхности частиц каолиновой и монтмориллонитовой глин уменьшается. Изменения гранулометрического состава обусловлены процессами агрегации и диспергации частиц. В процессе агрегации, вызванной высоким давлением, формируются коагуляционные, переходные и фазовые контакты между частицами. Дробление и расклинивающее давление пленки связанной воды вокруг частиц являются ведущими факторами, определяющими процесс их диспергации.

Karine A. Alvanyan - PhD student at the Department of Engineering Geology and Mineral Protection (tel.: +007 342 239 64 39, e-mail: karishuta@yandex.ru). The contact person for correspondence.

Aleksandr V. Rastegaev (Author ID in Scopus: 55531816900) - Doctor of Geology and Mineralogy, Professor of the Department of Geology of Oil and Gas Aleksandr V. Rastegaev (Author ID in Scopus: 5553
(tel.: +007 34221983 14, e-mail: arastegaev@mail.ru).

Tatyana Yu. Khludeneva - PhD student at the Department of Engineering Geology and Mineral Protection (tel.: +007 34223964 39, e-mail: seredin@nedra.perm.ru).

Алванян Карине Антоновна - аспирант кафедры инженерной геологии и охраны недр (тел.: +007 342239 64 39, e-mail: karishuta@yandex.ru). Контактное лицо для переписки.

Растегаев Александр Васильевич - доктор геолого-минералогических наук, профессор кафедры геологии нефти и газа (тел.: +007 2198000 , e-mail: arastegaev@mail.ru).

Хлуденева Татьяна Юрьевна - аспирант кафедры инженерной геологии и охраны недр (тел.: +007 342239 64 39, e-mail: seredin@nedra.perm.ru). 


\section{Introduction}

Physical and chemical properties of clays depend on factors determining energy potential on particle surface [1-4] and on factors forming particle specific surface $[5,6]$.

To form energy potential in clays various methods for their processing (activation): thermal [7-10], chemical, using acids [11], using alkali [12], using salts with different exposure duration [13].

According to data of B.K. Kara-Sal et al. [8], when heating clays to temperatures $400-600{ }^{\circ} \mathrm{C}$ their sorption activity increases due to release of high energy centers at mineral surface. By opinion of Zh.A. Sapronova et al. [14], during ultraviolet clay activation metallic ions move away from octahedral positions due to weakening links in mineral matrix. This aids to increase clay activity by 1,3 times. Ultrasound clay processing leads to destruction of aggregates and matrix completion, which increases clay activity [15].

A limited number of works is devoted to study of alteration of physical and chemical properties of pressure-processed kaolin. In most details these issues were dealt with by A. G. Kosovskaya et al. [16], V.A. Eroschev-Schak et al. [17], E.A. Goilo et al. [18], K.J. Rangeetal. [19], V.A. FrankKamenetzky et al. [20], LaIglesia [21], Galan et al. [22]. LaIglesia [21] established that action of pressure (100-2000 MPa) on kaolin does not lead to substantial change of coherent scattering area $d_{001}$ (energy potential), and at pressures over болеe $4000 \mathrm{MPa}$ these changes become manifested.

Particle specific surface forming is directly related to issues of microaggregate formation in soil $[1,23,24]$. Works [23, 25] provide information on formation of granulometric and microaggregate composition of wet clays in processes of their natural formation and transformation. Works $[5,6]$ publish information on clays subjected to man-made impact with $\mathrm{MgCl}_{2}, \mathrm{CaCl}_{2}, \mathrm{KCl}$ and $\mathrm{NaCl}$ solutions. The authors came to conclusion that aggregation process is related to concentration of salt solution and mineral composition of particles.

Issues of influence of a mechanical factor, for example, pressure, on aggregate formation in disperse wet soils were studied in works [25-27]. The studies performed [28] showed that at pressures up to $200 \mathrm{MPa}$ insignificant alteration of aggregate composition of raw soils is observed. At pressure of $300 \mathrm{MPa}$ on powdery soil this sandy fraction contents increased from 13 to $51 \%$, powdery fraction - from 5 to $23 \%$, and clay fraction - from 2,15 to $5,42 \%$. During tests of covering loams with pressure $P=2000 \mathrm{MPa}$ and $P$ $=3660 \mathrm{MPa}$ similar results were achieved [28]. On basis of experimental studies, forecasting methods for granulometric composition were developed not only for terrestrial [29], but also for lunar soils [30].

During clay pressure processing together with aggregation process also dispergation breaking processes take place. For kaolinite [21, 31-33] breaking changes particle size and form, and pores distribution. Except that, breaking influences physical and chemical properties of clays [34-38]. Breaking kaolinite does not lead to gradual increase of defectiveness for all crystallites present in the sample [39-42].

From the stated above it can be seen that issues of influence of pressure on formation of microaggregate composition, and consequently, physical and chemical properties of clays are of substantial interest.

That is why purpose of the work is to study regularities of alteration of composition of clays subjected to high pressure.

Object of the study are quaternary kaolin clay from Nizhne-Uvelskoe field in Chelyabinsk Region and Lobanovskaya claystone-like montmorillonite clay from Upper Permian Sheshminsky horizon.

\section{Methodology}

In order to pass pressure to clay sample high pressure device was designed and built[43]. Its working surfaces are made from hard alloy material, their surface is $S=0,75 \mathrm{~cm}^{2}$. Press PLG-20 was used as loading device.

Clay samples were prepared for granulometric analysis using method described in work [5]. Maximal pressure was $P=2200 \mathrm{MPa}$. In total were made 56 samples of montmorillonite clay and 65 samples of kaolin clay.

Granulometric composition of clays was determined using laser diffraction analyzer «Analyzette-22» according to method described in work [5].

Technical capabilities of the unit permit to measure particle size from 0,08 to $20000 \mu \mathrm{m}$. In work[25] it was noted that thin clay fraction less than $1 \mu \mathrm{m}$ substantially determines physical and chemical properties of clays. That is why, basing on unit 
capabilities and substantial influence of finely dispersed particles on soil properties, we have studied the following fractions $(\mu \mathrm{m}): F_{<0,1}, F_{0,1-0,2}$, $F_{0,2-0,5}, F_{0,5-1,0}, F_{1-2}, F_{2-5}, F_{5-50}$.

In total 319 determinations of granulometric composition of montmorillonite clay and 385 kaolin clay were performed.

It is necessary to note that particle size determination on this device was performed in the following way: first dispergation takes place, then particles are measured, so in result we should obtain granulometric composition of soil. However, reduction of $F_{<0,1}$ fraction shows that not all particles during dispergation process are destroyed to primary size, so we actually obtain microaggregate composition of soil. So, in the context of the issue being discussed, further in the text we use terms «granulometric and microaggregate composition».

\section{Findings}

Studies were performed in stages. In the first stage influence of pressure and mineral composition of clay on alteration of its fractional composition was studied. Experimental data are given in fig. 1, from which it is seen that correlation fields have similar character of alteration for various fractions. However, fields of fraction $\mathrm{F}_{<0,1}-\mathrm{F}_{2-5}$ of kaolin clay are above corresponding fields of montmorillonite clay, and for fraction $\mathrm{F}_{5-50}$ it is vice versa. This is because mineral composition of clays substantially influences on alteration of clay fractions content in soil.

To confirm conclusion on influence of mineral composition of clays on formation of their granulometric composition statistical methods [44] were used, calculation results are shown in table 1. As it can be seen from table 1, calculated values of Student's coefficient $\left(t_{\mathrm{p}}\right)$ for each studied fraction are higher than $t_{m}=0,03$, so we may consider that mineral composition exerts substantial influence on formation of fractional composition of pressurized soils. Student's criterion shows that sample population are statistically segregated.

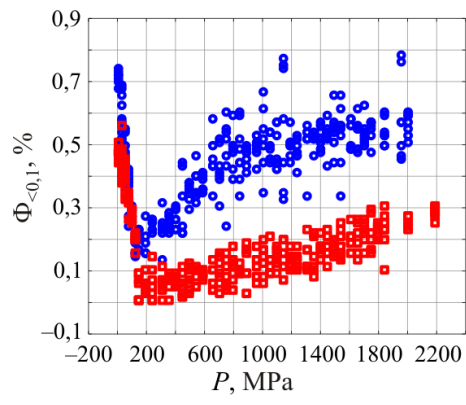

a

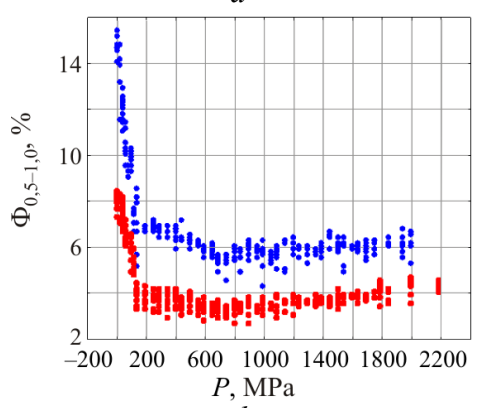

$d$

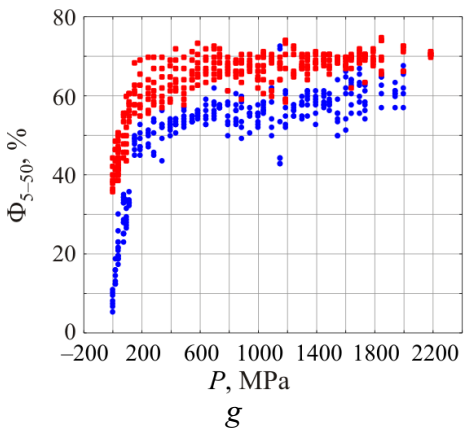

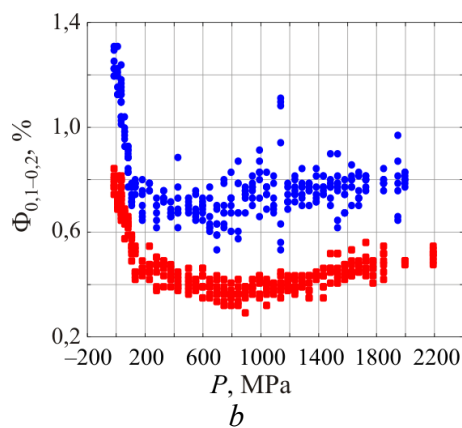
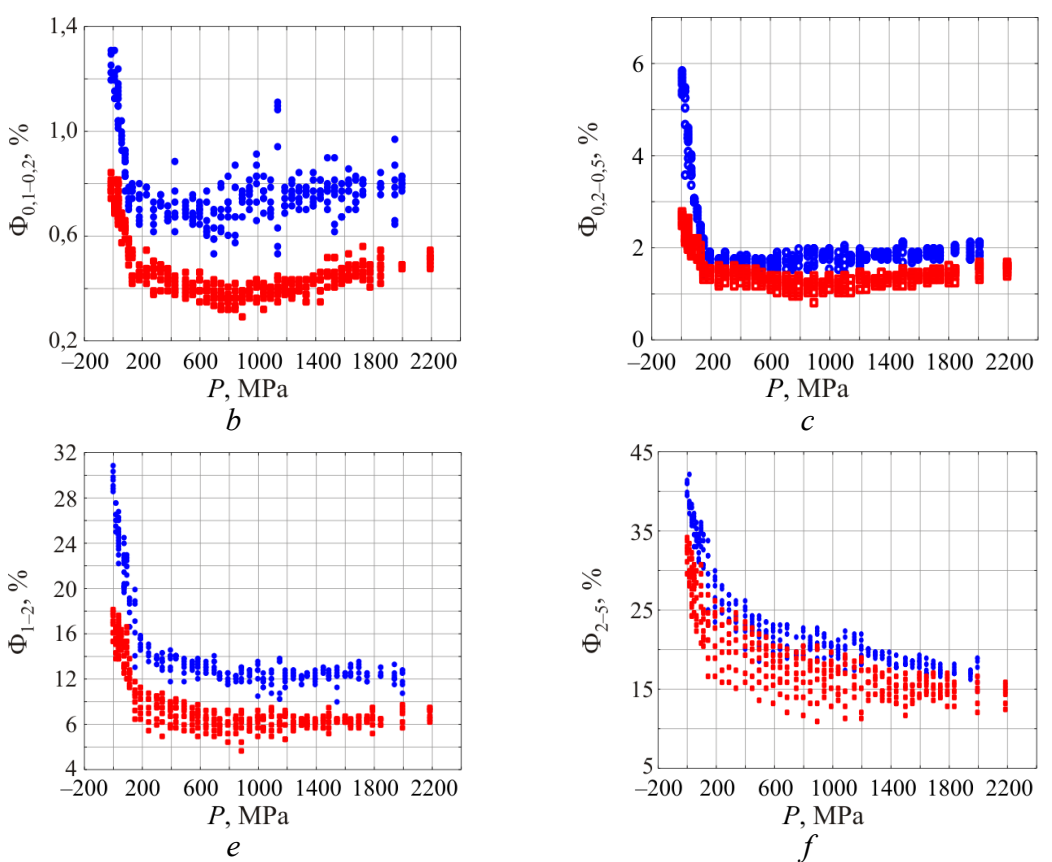

Kaolin

- Montmorillonite clay

Fig. 1. Alteration of fractional composition of montmorillonite and kaolin clays depending on pressure: $a-\mathrm{F}_{<0,1} ; b-\mathrm{F}_{0,1-0,2} ; c-\mathrm{F}_{0,2-0,5} ; d-\mathrm{F}_{1-2} ; e-\mathrm{F}_{2-5} ; f-\mathrm{F}_{5-50}$ 
Statistical characteristics of clays

\begin{tabular}{|c|c|c|c|c|c|c|c|c|}
\hline \multirow{2}{*}{$\begin{array}{c}\text { Fraction, } \\
\%\end{array}$} & \multicolumn{2}{|c|}{ Kaolin clay } & \multicolumn{2}{|c|}{ Montmorillonite clay } & \multirow{2}{*}{$\begin{array}{c}\text { Calculated value } \\
\text { of Student's } \\
\text { coefficient } t_{\mathrm{p}}\end{array}$} & \multicolumn{3}{|c|}{ Recognition of sample populations, $\%$} \\
\hline & Average & $\begin{array}{l}\text { Standard } \\
\text { deviation }\end{array}$ & Average & $\begin{array}{l}\text { Standard } \\
\text { deviation }\end{array}$ & & kaolin clay & $\begin{array}{c}\text { montmorillonite } \\
\text { clay }\end{array}$ & total \\
\hline $\mathrm{F}_{<0,1}$ & 0,449 & 0,139 & 0,180 & 0,120 & 25,911 & 80,0 & 85,9 & 83,0 \\
\hline $\mathrm{F}_{0,1-0,2}$ & 0,787 & 0,148 & 0,471 & 0,122 & 29,197 & 93,4 & 85,0 & 89,1 \\
\hline $\mathrm{F}_{0,2-0,5}$ & 2,184 & 0,938 & 1,508 & 0,397 & 11,801 & 42,3 & 83,4 & 63,3 \\
\hline $\mathrm{F}_{0,5-1,0}$ & 6,961 & 2,291 & 4,262 & 1,420 & 17,771 & 83,6 & 83,4 & 83,5 \\
\hline $\mathrm{F}_{1-2}$ & 14,637 & 4,538 & 9,673 & 2,798 & 16,526 & 67,5 & 82,1 & 75,0 \\
\hline $\mathrm{F}_{2-5}$ & 23,203 & 6,637 & 18,812 & 5,329 & 9,134 & 44,6 & 74,6 & 59,9 \\
\hline $\mathrm{F}_{5-50}$ & 49,961 & 13,960 & 62,695 & 9,197 & $-13,511$ & 58,4 & 81,8 & 70,4 \\
\hline$Z$ & $-1,759$ & 1,020 & 1,682 & 0,980 & $-42,967$ & 97,0 & 93,4 & 95,2 \\
\hline
\end{tabular}

Linear discriminant analysis was used for quantitative evaluation of segregation. Calculation results are given in table 1 . It is shown that maximal difference between kaolin and montmorillonite is observed for fractions $F_{0,1-0,2}$ and $F_{<0,1}$, and minimal for fraction $\mathrm{F}_{2-5}$.

Other fractions take intermediate position. For them criterion $t_{\mathrm{p}}$ changes from 9,1 to 17,8 , and general correctness of recognition - from 59,5 to $83,5 \%$. It is necessary to note that in the predominant majority of cases montmorillonite clay fractions are recognized better than those of kaolin clay.

In the second stage influence of pressure on general regularities of alteration of clay granulometric composition (separation of classes pressure range) was studied.

Alteration of clay fractional composition at increase of pressure is given in fig. 1. It is seen that at pressure increase to $P=125 \mathrm{MPa}$ significant reduction of clay fraction content $\left(\mathrm{F}_{<5}\right)$ and increase of powdery fraction content $\left(\mathrm{F}_{5-50}\right)$ is observed. At pressure increase to $P=750 \mathrm{MPa}$ content of clay fractions changes in different directions, and content of powdery fraction increases. At further pressure increase to $2200 \mathrm{MPa}$ clay fractions content increases, and powdery fraction content changes chaotically.

To confirm assumption of presence of threshold pressures $P=125 \mathrm{MPa}$ and $P=750 \mathrm{MPa}$ linear discriminant analysis was used. Discriminant functions calculations performed showed that correct recognition of all samples is $100 \%$.

Therefore, it is proved that threshold pressure values $P=125 \mathrm{MPa}$ and $P=750 \mathrm{MPa}$ are validly selected. This shows that in each class intensity of aggregation and dispergation processes is different, and so conditions of forming clay fractional composition also have their individual specifics.
In the third stage influence of pressure on alteration of clay granulometric composition within segregated classes (inside classes) was studied. Correlation analysis was used for this purpose.

In class $1(P=0-125 \mathrm{MPa})$ average content of clay fractions is less than in initial sample. This change is probably related to clay particles aggregation processes resulting in increase of powdery fraction $\mathrm{F}_{5-50}$ content.

Calculations showed that statistical links are established between $P$ and $\mathrm{F}$, which is confirmed by valid pair correlation coefficients $(r)$. Presence of negative $r$ values between $P$ and $\mathrm{F}_{<5}$ confirms our conclusion that along with pressure increase content of clay fractions decreases. Positive values of $r$ between pressure and powdery fraction content, on the opposite, mean that along with increase of $P$ content of $\mathrm{F}_{5-50}$ increases.

For evaluation of degree of pressure influence on alteration of studied fractions content parameter $k$ - angle coefficient was used, being tangent of straight line slope in equation of relation between pressure and fraction. It may be interpreted as follows: the higher are values of $k$, the greater influence pressure exerts on alteration of content of the studied fraction [32]. Calculation results are given in fig. 2.

It is established that along with particle size decrease influence of pressure on alteration of these fractions content decreases, while the most pressure-sensitive is powdery fraction $F_{5-50}$, and least sensitive - clay fraction $F_{<0,1}$. It is necessary to note that from all clay fractions to the greater extent sensitive to pressure are fractions $F_{1-2}$ and $F_{2-5}$ in montmorillonite and kaolin clay respectively.

Speed of change of clay fractions content in wet kaolin clay is higher comparing to montmorillonite clay, which is proved by higher values of $k$ (fig. 2). 

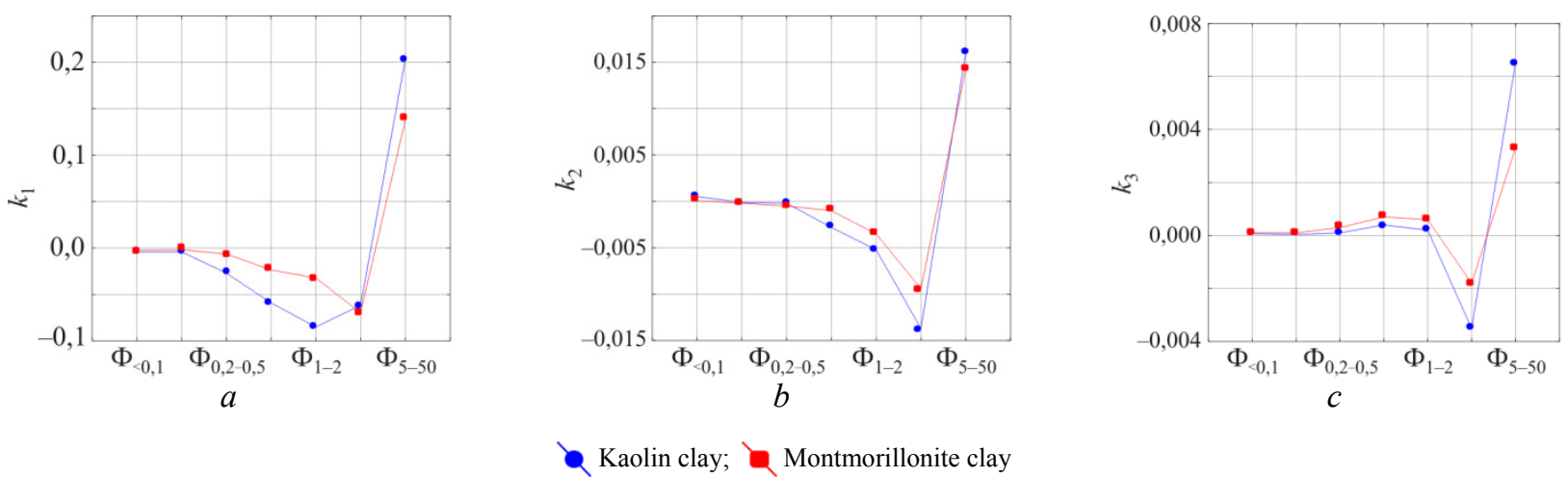

Fig. 2. Dependence of degree of pressure influence on alteration of content of studied fractions of kaolin and montmorillonite clays in classes $1(a), 2(b)$ and $3(c)$

In class $2(P=150-750 \mathrm{MPa})$, as in class 1 , Table 2 reduction of $\mathrm{F}_{<5}$ clay fraction content and increase of $F_{5-50}$ powdery fraction content is observed (see table 1). Meanwhile for fraction $F_{<0,1}$ other regularity is observed: along with pressure increase content of $F_{<0,1}$ increases, which is determined by dispergation processes of other fractions. Increase of $F_{5-50}$ content is related to processes of clay particles aggregation to powdery fraction sizes.

Of all clay fractions most pressure sensitive is fraction $\mathrm{F}_{2-5}$. Meanwhile pressure exerts greater influence on kaolin clay than on montmorillonite clay, which is proved by higher values of $k$ parameter.

In class $3(P=800-2200 \mathrm{MPa})$ influence of pressure on alteration of fractional composition of clays is crucially different from classes 1 and 2 . Along with pressure increase content of all fractions except $F_{2-5}$ increases, which is proved by positive values of $r$. Statistical links are established between $P$ and $\mathrm{F}$, proved by valid pair correlation coefficients. Maximal influence is exerted by pressure on formation of $F_{5-50}$ fraction, and minimal influence - on $F_{<0,1}$.

Of all clay fractions, as in both previous classes, most pressure-sensitive is fraction $\mathrm{F}_{2-5}$. Meanwhile pressure exerts more significant influence on kaolin clay that on montmorillonite clay, which is proved by higher values of $k$ parameter.

In the fourth stage influence of pressure on formation of particle specific surface of clay soils was studied. Results of study are given in fig. 3 . Calculation of particle specific surface was made per $1 \mathrm{~mm}^{3}$ of clay.

From fig. 3 it is seen that along with pressure increase area of particle specific surface of kaolin $\left(S_{\mathrm{K}}\right)$ and montmorillonite $\left(S_{\mathrm{M}}\right)$ clay reduces.

Correlation matrix

\begin{tabular}{|l|c|c|c|c|c|c|}
\hline \multirow{2}{*}{ Parameter } & \multicolumn{3}{|c|}{ Kaolin clay } & \multicolumn{3}{c|}{ Montmorillonite clay } \\
\cline { 2 - 7 } & $S_{\mathrm{K}_{1}}$ & $S_{\mathrm{K}_{2}}$ & $S_{\mathrm{K}_{3}}$ & $S_{\mathrm{M}_{1}}$ & $S_{\mathrm{M}_{2}}$ & $S_{\mathrm{M}_{3}}$ \\
\hline $\begin{array}{l}\text { Pressure } P, \\
\mathrm{MPa}\end{array}$ & $-0,98$ & $-0,55$ & 0,25 & $-0,88$ & $-0,61$ & 0,70 \\
\hline
\end{tabular}

Note: $S_{\mathrm{K}_{1}}, S_{\mathrm{M}_{1}}$ - area of specific (active) surfaces of particles in classes 1, 2, 3 .

Meanwhile the highest speed of $S$ reduction is observed in class 1 (at pressures up to $125 \mathrm{MPa}$ ). At pressure over $125 \mathrm{MPa}$ its influence on change of $S$ is less significant. In case of montmorillonite clay on qualitative level interrelation between pressure and surface is observed, while in kaolin clay the relation is not expressed.

For quantitative evaluation of interrelations between $P$ and $S$ correlation and regression analyses were used. Correlation analysis results are given in table 2.

From table 2 it is seen that statistical links are established between pressure and area of clay particle specific surface, which is proven by valid pair correlation coefficients. Calculated value of coefficient of correlation between area of clay particle specific surface in class 3 and pressure equal to $r_{p}=0,25$ is greater than critical value $r_{\mathrm{T}}=0,17$ at level of significance $\alpha=0,05$ and number of freedom degree $n=160$.

In the fifth stage conditions of forming granulometric composition of clays subjected to pressure were studied. During processing clays with pressure particle breaking and aggregation processes are observed in studied samples. Aggregation process is determined by forces of particle interaction between themselves being of physical and chemical nature, and 
breaking process - by deformations of particles. Let us study influence of pressure on aggregation and dispergation of particles in aspect of their size.
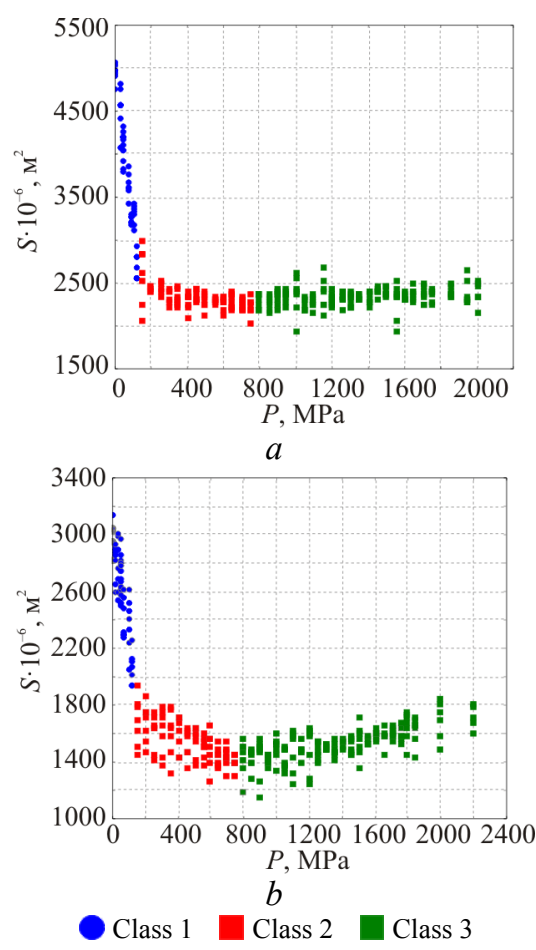

Fig. 3. Alteration of specific surface area in kaolin $(a)$ and montmorillonite $(b)$ clays depending on pressure

In crystallites aggregation process takes place according to the following scenario: at pressure $P=0 \mathrm{MPa}$ (in natural clays) crystallites are interlinked by molecular bonds (through cations of diffuse water layers), i.e. link between crystallites is performed by coagulation contacts. At pressure on soil from 0 to $125 \mathrm{MPa}$ adsorbed water films (diffuse layers) on crystallite surface [45] partially break, that is why crystallites contact between themselves, on one part, in a point-like manner (transition contacts), and on the other part, through diffuse layers (coagulation contacts). At pressure increase from 125 to $2000 \mathrm{MPa}$ aggregation process is changed by crystallite dispergation process, due to which partial destruction of chemical bonds between crystallites occurs. Reason of this destruction is wedging pressure of adhesive water film, formed by increased energy potential on crystallite surface. That is, we observe reduction of influence in aggregate of point-like contacts (electrostatic and chemical bonds) and increase of weaker coagulation contacts (molecular bonds), and number of contacts between crystallites breaks fully.

In fine colloids (size of $0,1-2,0 \mu \mathrm{m}$ ) at pressure up to $125 \mathrm{MPa}$ aggregation processes follow the above scenario. At pressure from 125 to $2200 \mathrm{MPa}$ intensity of aggregation and dispergation processes is insignificant, the compensate each other, that is why content of these fractions changes rather weakly.

In coarse colloids (size of $2-5 \mu \mathrm{m}$ ) at pressure from 0 to $2200 \mathrm{MPa}$ only aggregation processes happen, with different formation mechanism and intensity. At pressure increase from 0 to $125 \mathrm{MPa}$ number of breakthrough points in adsorbed water films (diffuse layers) on crystallites surface increases, leading to reduction of coagulation contacts and increase of transition contacts. Therefore, we see reduction of molecular and increase of chemical bonds between colloids. At further increase of pressure from 125 to $800 \mathrm{MPa}$ number of transition contacts increases and individual phase contacts appear. That is, role of chemical bonds between colloids increases. At further pressure increase from 800 to $2200 \mathrm{MPa}$ role of chemical contacts between colloids (phase contacts) prevails. The obtained results do not contradict to nature of forming microaggregate composition of clays.

\section{Conclusions}

It is experimentally established that along with pressure increase general tendency of reduction of clay fraction content and increase of powdery fraction content is observed. Together with this regularity, in each class local alterations of clay fraction composition depending on pressure are found. With pressure increase, area of particle specific surface in kaolin and montmorillonite clays decreases. Alterations in granulometric composition are determined by particle aggregation and dispergation processes. In aggregation process, caused by high pressure, coagulation, transition and phase contacts between particles are formed. Breaking and wedging pressure of adsorbed water film around particles are leading factors determining process of particle dispergation.

\section{References}

1. Osipov V.I., Sokolov V.N., Rumiantseva N.A. Mikrostruktura glinistykh porod [Micro structure of clay rocks]. Moscow, Nedra, 1989, 211 p.
2. Seredin V.V., Krasilnikov P.A., Medvedeva N.A. izmenenie elek-trokineticheskogo potentsiala glinistykh kolloidov v vodnoi i uglevodorodnoi sredakh [Variation 
of electrokinetic potential of clayey colloids in aquatic and hydrocarbon media]. Geoekologiia. Inzhenernaia geologiia, gidrogeologiia, geokriologiia, 2017, no.1, pp.66-74.

3. Seredin V.V., Krasilnikov P.A., Medvedeva N.A., Parshina T.Iu., Peshkova T.A. Zakonomernosti izmeneniia strukturnykh sviazei (elektrokineticheskogo potentsiala) glinistykh chastits v vodnom rastvore [Laws changes of structural links (zeta potential) of particles clay in aqueous solution]. Sovremennye problemy nauki i obrazovaniia, 2015, no.2-2, p.888.

4. Seredin V.V., Parshina T.Y., Rastegaev A.V., Galkin V.I., Isaeva G.A. Changes of energy potential on clay particle surfaces at high pressures. Applied Clay Science, 2018, vol.155, pp.8-14. DOI: 10.1016/j.clay.2017.12.042

5. Seredin V.V., Rastegaev A.V., Medvedeva N.A., Parshina T.Iu. Vliianie davleniia na ploshchad aktivnoi poverkhnosti chastits glinistykh gruntov [The effect of pressure on the active surface area of clay soil particles]. Inzhenernaia geologiia, 2017, no.3, pp.18-27. DOI: 10.25296/1993-5056-2017-3-18-27

6. Parshina T.Iu., Seredin V.V. Formirovanie mikroagregatnogo sostava glin pri ikh szhatii [The formation microaggregate composition of clays during their compression]. Sovremennye tekhnologii v stroitelstve. teoriia i praktika, 2017, vol.2, pp.142-146.

7. Tuchkova A.I., Tiupina E.A. Vliianie temperatury aktivatsii bentonita na ego sorbtsionnuiu sposobnost $\mathrm{k}$ izvlecheniiu Cs-137 iz vakumnykh masel [The effect of the activation temperature of bentonite on its sorption ability to extract Cs-137 from vacuum oils]. Uspekhi v khimii i khimicheskoi tekhnologii, 2010, vol.24, 7(112), pp.12-15.

8. Kara-Sal B.K., Sapelkina T.V. Povyshenie adsorbtsionnykh svoistv glinistykh porod Tuvy $\mathrm{v}$ zavisimosti ot metodov aktivatsii [Increasing the adsorption properties of clay rocks of Tuva, depending on the activation methods]. Aktualnye problemy sovremennoi nauki, 2012, no.5, pp.158-162.

9. Binnatova L.A. et al. Termoobrabotka bentonita i adsorbtsiia metilena golubogo [Heat treatment of bentonite and methylene blue adsorption]. Kondensirovannye sredy i mezhfaznye granitsy, 2007, vol.9, no.2, pp.99-101.

10. Belchinskaia L.I. et al. Vliianie termicheskogo modifitsirovaniia na adsorbtsionnye svoistva prirodnykh silikatov [Effect of thermal modification on the adsorption properties of natural silicates]. Sorbtsionnye i khromato-graficheskie protsessy, 2006, vol.6, iss.1, pp.80-81.
11. Mostalygina L.V., Chernova E.A., Bukhtoiarov O.I. Kislotnaia aktivatsiia bentonitovoi gliny [Acid

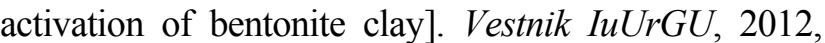
no.24, pp.57-61.

12. Tuchkova A.I., Tiupina E.A., Rakhimov M.G. Vliianie shchelochnoi aktivatsii glinistykh mineralov na ikh sorbtsionnuiu sposobnost $\mathrm{k}$ izvlecheniiu Cs-137 iz otrabotannogo masla [The effect of alkaline activation of clay minerals on their sorption ability to extract Cs-137 from waste oil]. Uspekhi v khimii i khimicheskoi tekhnologii, 2012, vol.26, 6 (135), pp.92-55.

13. Kurtukova L.V., Somin V.A., Komarova L.F. Issledovaniia po udaleniiu iz vody solei zhestkosti $\mathrm{s}$ primeneniem sorbentov na osnove mineralnykh volokon $\mathrm{i}$ bentonitovykh glin [Studies on the removal of hardness salts from water using sorbents based on mineral fibers and bentonite clays]. Uspekhi sovremennogo estestvoznaniia, 2011, no.12, pp.29-31.

14. Sapronova Zh.A., Lesovik V.S., Gomes M.Zh., Shaikhieva K.I. Sorbtsionnye svoistva UF-aktivirovannykh glin angolskikh mestorozhdenii [Sorption properties of UV-activated clays of the Angolan deposits]. Vestnik KazNITU, 2015, vol.18, no.1, pp.91-93.

15. Pushkareva G.I. Vliianie temperaturnoi obrabotki brusita na ego sorbtsionnye svoistva [The effect of thermal treatment of brucite on its sorption properties]. Fiziko-tekhnicheskie problemy razrabotki poleznykh iskopaemykh, 2000, no.6, pp.90-93.

16. Kossovskaia A.G., Shutov V.D., Drits V.A. Glinistye mineraly - indikatory glubinnogo izmeneniia terrigennykh porod [Clay minerals - indicators of deep changes in terrigenous rocks]. Geokhimiia, mineralogiia i petrografiia osadochnykh obrazovanii. Ed. D.I. Shcherbakov. Moscow, Izdatelstvo AN SSSR, 1963.

17. Eroshchev-Shak V.A., Bogatyrev B.A. Razmernost i forma mineralov semeistva kaolinita raznogo genezisa i vozrasta [The dimension and shape of the kaolinite family of minerals of different genesis and age]. Kontseptualnye problemy litologicheskikh issledovanii v Rossii. Kazan, 2011. vol.1, pp.293-297.

18. Goilo E.A., Kotov N.V., Frank-Kamenetskii V.A. Eksperimentalnoe issledovanie vliianiia davleniia i temperatury na kristallicheskie struktury kaolinita, illita i montmorillonita [Experimental study of the effect of pressure and temperature on the crystal structures of kaolinite, illite and montmorillonite]. Fizicheskie metody issledovaniia osadochnykh porod. Moscow, Nauka, 1966, pp.123-129. 
19. Range K.J., Range A., Weiss A. Fire-clay type kaolinite or fire-clay mineral Experimental classification of kaolinite-halloysite minerals. Proc. Int. Clay Conf, Tokyo, 1969, pp.3-13.

20. Frank-Kamenetskii V.A., Kotov N.V., Goilo E.A. Izmenenie struktury glinistykh mineralov $\mathrm{v}$ razlichnykh termodinamicheskikh usloviiakh [Changes in the structure of clay minerals in different thermodynamic conditions]. Rentgenografiia mineralnogo syria, 1970, no.7, pp.166-174.

21. La Iglesia A. Pressure induced disorder in kaolinite. Clay Minerals, 1993, vol.28, pp.311-319. DOI: 10.1180/claymin.1993.028.2.11

22. Galan E., Aparicio P., Gonzalez Â. The effect of pressure on order/disorder in kaolinite under wet and dry conditions. Clays and Clay Minerals, 2006, vol.54, no.2, pp.230-239. DOI: 10.1346/CCMN.2006.0540208

23. Osovetskii B.M. Drobnaia granulometriia alliuviia [Fractional alluvium granulometry]. Perm, Izdatelstvo Permskogo universiteta, 1993, $343 \mathrm{p}$.

24. Savko A.D., Sviridov V.A. Evoliutsiia mineralnogo sostava glin $\mathrm{v}$ zavisimosti ot uslovii ikh sedimentatsii i diageneza (na primere kainozoiskikh otlozhenii Voronezhskoi anteklizy) [The evolution of the mineral composition of clays depending on the conditions of their sedimentation and diagenesis (on the example of the Cenozoic deposits of the Voronezh anteclise)]. Evoliutsiia osadochnykh protsessov $v$ istorii Zemli. Materialy VIII Vserossiiskogo litologicheskogo soveshchaniia, Moscow, 2015, pp.293-296.

25. Krivosheeva Z.A., Zlochevskaia R.I., Korolev V.A., Sergeev E.M. O prirode izmeneniia sostava i svoistv glinistykh porod $\mathrm{v}$ protsesse litogeneza [On the nature of changes in the composition and properties of clay rocks in the process of lithogenesis]. Vestnik Moskovskogo universiteta. Seriia Geologiia, 1977, no.4, pp.60-73.

26. Stefani V.F., Conceição R.V., Balzaretti N.M., Carniel L.C. Stability of lanthanum-saturated montmorillonite under high pressure and high temperature conditions. Applied Clay Science, 2014, vol.102, pp.51-59. DOI: 10.1016/j.clay.2014.10.012

27. Friedlander L.R., Glotch T.D., Phillips B.L., Vaughn J.S., Michalski J.R. Examining structural and related spectral change in marsrelevant phyllosilicates after experimental impacts between 10-40 gpa. Clays and Clay Minerals, 2016, vol.64, no.3, pp.189-209. DOI: 10.1346/CCMN.2016.0640302

28. Sergeev E.M. K voprosu uplotneniia pylevatogo grunta bolshimi nagruzkami [To the issue of compaction of silty soil with heavy loads]. Vestnik Moskovskogo universiteta, 1946, no.1, pp.91-93.

29. Boiko V.F., Verkhoturov A.D., Ershova T.B., Vlasova N.M. Zavisimost granulometricheskikh kharakteristik dispersnogo brusita ot sroka khraneniia [The dependence of the particle size characteristics of dispersed brucite on the shelf life]. Ogneupory $i$ tekhnicheskaia keramika, 2009, no.6, pp.47-49.

30. Korolev V.A. Modelirovanie granulometricheskogo sostava lunnykh gruntov [Simulation of the particle size distribution of lunar soils]. Inzhenernaia geologiia, 2016, no.5, pp.40-50.

31. Ehrenberg S.N., Aagaard P., Wilson M.J., Fraser A.R., Duthie D.M.L. Depth-dependent transformation of kaolinite to dickite in sandstones of the Norwegian continental shelf. Clay Minerals, 1993, vol.28, pp.325-352. DOI: 10.1180/claymin.1993.028.3.01

32. Ruiz Cruz M.D., Andreo B. Genesis and transformation of dickite in Permo-Triassic sediments (Betic Cordilleras, Spain). Clay Minerals, 1996, vol.31, pp.133-152. DOI: 10.1180/claymin.1996.031.2.01

33. Sun D., Zhang L., Zhang B., Li J. Evaluation and prediction of the swelling pressures of gmz bentonites saturated with saline solution. Applied Clay Science, 2015, vol.105-106, pp.207-216. DOI: $10.1016 /$ j.clay.2014.12.032

34. Seredin V.V., Rastegayev A.V., Panova E.G., Medvedeva N.A. Changes in physical-chemical properties of clay under compression. International Journal of Engineering and Applied Sciences. 2017, vol.4, no.3, pp.22-29.

35. Hills J.F., Pettifer G.S. The clay mineral content of various rock types compared with the methylene blue value. Journal of Chemical Technology and Biotechnology, 1985, vol.35A, pp.168-180. DOI: 10.1002/jctb.5040350404

36. Yeliz Yukselen, Abidin Kaya. Suitability of the methylene blue test for surface area, cation exchange capacity and swell potential determination of clayey soils. Engineering Geology, 2008, vol.102, iss.1-2, pp.38-45. DOI: $10.1016 /$ j.enggeo.2008.07.002

37. Tang L., Sparks D.L. Cation-exchange kinetics on montmorillonite using pressurejump relaxation. Soil Science Society of America Journal, 1993, vol.57, no.1, pp.42-46. DOI:10.2136/sssaj 1993.03615995005700010009x

38. Bhattacharyya K.G., Gupta S.S. Adsorption of a few heavy metals on natural and modified kaolinite and 
montmorillonite: A review. Advances in Colloid and Interface Science, 2008, no.140, pp.114-131. DOI: $10.1016 /$ j.cis.2007.12.008

39. Guo Yu., Xiong (Bill) Yu. Characterizing the surface charge of clay minerals with Atomic Force Microscope (AFM). AIMS Materials Science, 2017, vol.4, no.3, pp.582-593 (12). DOI: $10.3934 /$ matersci.2017.3.582

40. Klaassen A., Liu F., Van den Ende D., Mugele F., Siretanu I. Impact of surface defects on the surface charge of gibbsite nanoparticles. Nanoscale, 2017, 9 (14), pp.4721-4729. DOI: $10.1039 / \mathrm{c} 6 \mathrm{nr} 09491 \mathrm{k}$

41. Zhou Z., Gunter W.D. The nature of the surface charge of kaolinite. Clays and Clay Minerals, 1992, vol.40, pp.365-368. DOI: 10.1346/CCMN.1992.0400320

42. Zhu X., Zhu Z., Lei X., Yan C. Defects in structure as the sources of the surface charges of kaolinite. Appl. Clay Sci, 2016, vol.124-125, pp.127-136. DOI: 10.1016/j.clay.2016.01.033

43. Seredin V.V., Rastegaev A.V., Galkin V.I., Parshina T.Iu., Isaeva G.A. Vliianie davleniia i granulometricheskogo sostava na energeticheskuiu aktivnost glin [Influence of pressure and particlesize composition on energy activity of clay]. Inzhenernaia geologiia, 2017, no.4, pp.62-71. DOI: 10.25296/1993-5056-2017-4-62-71

44. Galkin V.I., Rastegaev A.V., Galkin S.V. Veroiatnostno-statisticheskaia otsenka neftegazonostnosti lokalnykh struktur [Probabilisticstatistical evaluation of the petroleum potential of local structures]. Ekaterinburg, UrO RAN, $2001,277 \mathrm{p}$

45. Seredin V.V., Parshina T.Iu. Mass change of bound water in clays under compression. Perm Journal of Petroleum and Mining Engineering, 2017, vol.16, no.1, pp.23-32. DOI: 10.15593/2224-9923/2017.1.3

\section{Библиографический список}

1. Осипов В.И., Соколов В.Н., Румянцева Н.А. Микроструктура глинистых пород. - Москва: Недра, 1989. - 211 с.

2. Середин В.В., Красильников П.А., Медведева Н.А. Изменение электрокинетического потенциала глинистых коллоидов в водной и углеводородной средах // Геоэкология. Инженерная геология, гидрогеология, геокриология. - 2017. - № 1. - С. 66-74.

3. Закономерности изменения структурных связей (электрокинетического потенциала) глинистых частиц в водном растворе / В.В. Середин, П.А. Красильников, Н.А. Медведева, Т.Ю. Паршина, Т.А. Пешкова // Современные проблемы науки и образования. - 2015. № 2-2. - C. 888 .

4. Changes of energy potential on clay particle surfaces at high pressures / V.V. Seredin, T.Y. Parshina, A.V. Rastegaev, V.I. Galkin, G.A. Isaeva // Applied Clay Science. - 2018. - Vol. 155. - P. 8-14. DOI: 10.1016/j.clay.2017.12.042

5. Влияние давления на площадь активной поверхности частиц глинистых грунтов / В.В. Середин, А.В. Растегаев, Н.А. Медведева, Т.Ю. Паршина // Инженерная геология. - 2017. № 3. - C. 18-27. DOI: 10.25296/1993-5056-2017-3-18-27

6. Паршина Т.Ю., Середин В.В. Формирование микроагрегатного состава глин при их сжатии // Современные технологии в строительстве. Теория и практика. - 2017. - Т. 2. - С. 142-146.
7. Тучкова А.И., Тюпина Е.А. Влияние температуры активации бентонита на его сорбционную способность к извлечению Cs-137 из вакуумных масел // Успехи в химии и химической технологии: сборник научных трудов. - 2010. T. 24, 7 (112). - C. 12-15.

8. Кара-Сал Б.К., Сапелкина Т.В. Повышение адсорбционных свойств глинистых пород Тувы в зависимости от методов активации // Актуальные проблемы современной науки. - 2012 - № 5 . C. $158-162$.

9. Термообработка бентонита и адсорбция метилена голубого / Л.А. Биннатова [и др.] // Конденсированные среды и межфазные границы. 2007. - T. 9, № 2. - C. 99-101.

10. Влияние термического модифицирования на адсорбционные свойства природных силикатов / Л.И. Бельчинская [и др.] // Сорбционные и хроматографические процессы. - 2006. - Т. 6, вып. 1. - С. 80-81.

11. Мосталыгина Л.В., Чернова Е.А., Бухтояров О.И. Кислотная активация бентонитовой глины // Вестник ЮУрГУ. - 2012. - № 24. C. 57-61.

12. Тучкова А.И., Тюпина Е.А., Рахимов М.Г. Влияние щелочной активации глинистых минералов на их сорбционную способность к извлечению Cs-137 из отработанного масла // Успехи в химии и химической технологии: 
сборник научных трудов. - 2012. - Т. 26, 6 (135). - C. 92-55.

13. Куртукова Л.В., Сомин В.А., Комарова Л.Ф. Исследования по удалению из воды солей жесткости с применением сорбентов на основе минеральных волокон и бентонитовых глин // Успехи современного естествознания. - 2011. № 12. - C. 29-31.

14. Сорбционные свойства УФ-активированных глин Ангольских месторождений / Ж.А. Сапронова, В.С. Лесовик, М.Ж. Гомес, К.И. Шайхиева // Вестник КазНИТУ. - 2015. Т. 18, № 1. - C. 91-93.

15. Пушкарева Г.И. Влияние температурной обработки брусита на его сорбционные свойства // Физико-технические проблемы разработки полезных ископаемых. - 2000. - № 6. - С. 90-93.

16. Коссовская А.Г., Шутов В.Д., Дриц В.А. Глинистые минералы - индикаторы глубинного изменения терригенных пород // Геохимия, минералогия и петрография осадочных образований / под ред. акад. Д.И. Щербакова. Москва: Изд-во АН СССР, 1963.

17. Ерощев-Шак В.А., Богатырев Б.А. Размерность и форма минералов семейства каолинита разного генезиса и возраста // Концептуальные проблемы литологических исследований в России. Казань, 2011. - Т. 1. - С. 293-297.

18. Гойло Э.А., Котов Н.В., Франк-Каменецкий В.А. Экспериментальное исследование влияния давления и температуры на кристаллические структуры каолинита, иллита и монтмориллонита // Физические методы исследования осадочных пород. - Москва: Наука, 1966. C. $123-129$.

19. Range K.J., Range A., Weiss A. Fire-clay type kaolinite or fire-clay mineral Experimental classification of kaolinite-halloysite minerals // Proc. Int. Clay Conf. - Tokyo, 1969. P. 3-13.

20. Франк-Каменецкий В.А., Котов Н.В., Гойло Э.А. Изменение структуры глинистых минералов в различных термодинамических условиях // Рентгенография минерального сырья. 1970. - № 7. - C. 166-174.

21. La Iglesia A. Pressure induced disorder in kaolinite // Clay Minerals. - 1993. - Vol. 28. P. 311-319. DOI: 10.1180/claymin.1993.028.2.11

22. Galan E., Aparicio P., Gonzalez Â. The effect of pressure on order/disorder in kaolinite under wet and dry conditions // Clays and Clay Minerals. -
2006. - Vol. 54, no. 2. - P. 230-239. DOI: 10.1346/CCMN.2006.0540208

23. Осовецкий Б.М. Дробная гранулометрия аллювия. - Пермь: Изд-во Перм. ун-та, 1993. - 343 с.

24. Савко А.Д., Свиридов В.А. Эволюция минерального состава глин в зависимости от условий их седиментации и диагенеза (на примере кайнозойских отложений Воронежской антеклизы) // Эволюция осадочных процессов в истории Земли: Материалы VIII Всероссийского литологического совещания. - Москва, 2015. - C. 293-296.

25. О природе изменения состава и свойств глинистых пород в процессе литогенеза / 3.А. Кривошеева, Р.И. Злочевская, В.А. Королев, Е.М. Сергеев // Вестник Московского университета. Серия Геология. - 1977. - № 4. - С. 60-73.

26. Stability of lanthanum-saturated montmorillonite under high pressure and high temperature conditions / V.F. Stefani, R.V. Conceição, N.M. Balzaretti, L.C. Carniel // Applied Clay Science. - 2014. - T. 102. - P. 51-59. DOI: $10.1016 /$ j.clay.2014.10.012

27. Examining structural and related spectral change in marsrelevant phyllosilicates after experimental impacts between 10-40 gpa / L.R. Friedlander, T.D. Glotch, B.L. Phillips, J.S. Vaughn, J.R. Michalski // Clays and Clay Minerals. - 2016. - Vol. 64, № 3. - P. 189-209. DOI: 10.1346/CCMN.2016.0640302

28. Сергеев Е.M. К вопросу уплотнения пылеватого грунта большими нагрузками // Вестник Московского университета. - 1946. № 1. - С. 91-93.

29. Зависимость гранулометрических характеристик дисперсного брусита от срока хранения / В.Ф. Бойко, А.Д. Верхотуров, Т.Б. Ершова, Н.М. Власова // Огнеупоры и техническая керамика. - 2009. - № 6. - С. 47-49.

30. Королев В.А. Моделирование гранулометрического состава лунных грунтов // Инженерная геология. - 2016. - № 5. - С. 40-50.

31. Depth-dependent transformation of kaolinite to dickite in sandstones of the Norwegian continental shelf / S.N. Ehrenberg, P. Aagaard, M.J. Wilson, A.R. Fraser, D.M.L. Duthie // Clay Minerals. - 1993. Vol. 28. - P. 325-352. DOI: 10.1180/claymin.1993.028.3.01

32. Ruiz Cruz M.D., Andreo B. Genesis and transformation of dickite in Permo-Triassic sediments (Betic Cordilleras, Spain) // Clay Minerals. - 1996. Vol. 31.-P. 133-152. DOI: 10.1180/claymin.1996.031.2.01 
33. Evaluation and prediction of the swelling pressures of $\mathrm{gmz}$ bentonites saturated with saline solution / D. Sun, L. Zhang, B. Zhang, J. Li // Applied Clay Science. - 2015. - Vol. 105-106. P. 207-216. DOI: 10.1016/j.clay.2014.12.032

34. Changes in physical-chemical properties of clay under compression / V.V. Seredin, A.V. Rastegayev, E.G. Panova, N.A. Medvedeva // International Journal of Engineering and Applied Sciences. - 2017. - Vol. 4, № 3. - P. 22-29.

35. Hills J.F., Pettifer G.S. The clay mineral content of various rock types compared with the methylene blue value // Journal of Chemical Technology and Biotechnology. - 1985. - Vol. 35A. P. 168-180. DOI: $10.1002 /$ jctb.5040350404

36. Yeliz Yukselen, Abidin Kaya. Suitability of the methylene blue test for surface area, cation exchange capacity and swell potential determination of clayey soils // Engineering Geology. - 2008. - Vol. 102, iss. 1-2. - P. 38-45. DOI: 10.1016/j.enggeo.2008.07.002

37. Tang L., Sparks D.L. Cation-exchange kinetics on montmorillonite using pressurejump relaxation // Soil Science Society of America Journal. - 1993. - Vol. 57, № 1. - P. 42-46. DOI:10.2136/sssaj1993.03615995005700010009x

38. Bhattacharyya K.G., Gupta S.S. Adsorption of a few heavy metals on natural and modified kaolinite and montmorillonite: A review // Advances in Colloid and Interface Science. - 2008. - № 140. P. 114-131. DOI: 10.1016/j.cis.2007.12.008

39. Guo Yu., Xiong (Bill) Yu. Characterizing the surface charge of clay minerals with Atomic
Force Microscope (AFM) // AIMS Materials Science. - 2017 - Vol. 4, № 3. - P. 582-593. DOI: $10.3934 /$ matersci.2017.3.582

40. Impact of surface defects on the surface charge of gibbsite nanoparticles / A. Klaassen, F. Liu, D. Van den Ende, F. Mugele, I. Siretanu // Nanoscale. - 2017. - 9 (14). - P. 4721-4729. DOI: $10.1039 / \mathrm{c} 6 \mathrm{nr} 09491 \mathrm{k}$

41. Zhou Z., Gunter W.D. The nature of the surface charge of kaolinite // Clays and Clay Minerals - 1992. - Vol. 40. - P. 365-368. DOI: 10.1346/CCMN.1992.0400320

42. Defects in structure as the sources of the surface charges of kaolinite / X. Zhu, Z. Zhu, X. Lei, C. Yan // Appl. Clay Sci. - 2016. - Vol. 124-125. - P. 127-136. DOI: 10.1016/j.clay.2016.01.033

43. Влияние давления и гранулометрического состава на энергетическую активность глин / В.В. Середин, А.В. Растегаев, В.И. Галкин, Т.Ю. Паршина, Г.А. Исаева // Инженерная геология. - 2017. - № 4. - С. 62-71. DOI: 10.25296/1993-5056-2017-4-62-71

44. Галкин В.И., Растегаев А.В., Галкин С.В. Вероятностно-статистическая оценка нефтегазоностности локальных структур. Екатеринбург: Уро РАН, 2001. - 277 с.

45. Середин В.В., Паршина Т.Ю. Изменение массы связанной воды в глинах при сжатии // Вестник Пермского национального исследовательского политехнического университета. Геология. Нефтегазовое и горное дело. - 2017 - Т. 16, № 1 C. 23-32. DOI: 10.15593/2224-9923/2017.1.3

Please cite this article in English as:

Alvanyan K.A., Rastegaev A.V., Khludeneva T.Yu. Alteration in composition of clays subjected to man-made impact. Perm Journal of Petroleum and Mining Engineering, 2019, vol.19, no.2, pp.117-127. DOI: 10.15593/2224-9923/2019.2.2

Просьба ссылаться на эту статью в русскоязычных источниках следующим образом:

Алванян К.А., Растегаев А.В., Хлуденева Т.Ю. Изменение состава глин, подверженных техногенному воздействию // Вестник Пермского национального исследовательского политехнического университета. Геология. Нефтегазовое и горное дело. - 2019. - Т.19, №2. - C.117-127. DOI: 10.15593/2224-9923/2019.2.2 